\title{
Endometrial Large Cell Neuroendocrine Carcinoma
}

National Cancer Institute

\section{Source}

National Cancer Institute. Endometrial Large Cell Neuroendocrine Carcinoma. NCI

Thesaurus. Code C126772.

A high grade neuroendocrine neoplasm that arises from the endometrium. It is

composed of large polygonal cells arranged in well-demarcated nests, trabeculae or cords with peripheral palisading. 